Yatsenko, O., Nitsenko, V., Karasova, N., James, H.S.Jr., \& Parcell, J.L. (2017).

Realization of the potential of the Ukraine-EU free trade area in agriculture.

Journal of International Studies, 10(2), 258-277. doi:10.14254/2071-8330.2017/10-

$2 / 18$

\title{
Realization of the potential of the Ukraine-EU free trade area in agriculture
}

\author{
Olha Yatsenko \\ Kyiv National Economic University named after Vadym Hetman, \\ Kyiv, Ukraine \\ Email:yacenko_olga@ukr.net
}

\section{Vitalii Nitsenko}

Odessa I.I. Mechnikov National University, Odessa, Ukraine

Email:vitaliinitsenko@gmail.com

\section{Nataliia Karasova}

National Scientific Center "Institute of Agricultural Economics", Kyiv, Ukraine

Email: nkarasyova.natasha@gmail.com

\section{Harvey S. James, Jr.}

University of Missouri,

Columbia, Missouri, USA

Email:HJames@missouri.edu

\section{Joe L. Parcell}

University of Missouri,

Columbia, Missouri, USA

Email:parcell@@missouri.edu

Abstract. The Deep and Comprehensive Free Trade Area (DCFTA) Agreement between Ukraine and the EU has led to the following question: What new opportunities are unveiled for the agricultural sector? The aim of this article is to determine the promising trends in Ukrainian agriculture's export potential considering the potential adverse effects from highly competitive markets. The authors' gravity model is based on the research of the Ukraine-EU free trade area operating conditions. The paper provides a forecast on the volumes of trade flows of agricultural food products between the participants of the Agreement and determines advantages and disadvantages of trade and overall economic relationship liberalization. Finally, the ways to improve bilateral relations for Ukraine are proposed.

Keywords: free trade area, Ukraine, agricultural sector, export-oriented production.
Received: December, 2016 1st Revision: May, 2017 Accepted: May, 2017 DOI: $8330.2017 / 10-2 / 18$

JEL Classification: Q17, F15 


\section{INTRODUCTION}

Conclusion of the Deep and Comprehensive Free Trade Area (DCFTA) Agreement between Ukraine and EU (European Commission 2014, Shirmammadov, 2015) includes the creation of favorable conditions for future cooperation between specific countries or groups of countries. The powerful export potential of Ukraine's agriculture as well as objective local and global changes at the food and primary commodity markets create opportunities for intensification of trade and economic activities of Ukraine with the European Union countries in the context of providing a preferential trade regime.

Irrespective of the instability of the macroeconomic environment, the agricultural sector of Ukraine is one of the few branches of economy which has demonstrated a positive foreign trade balance in the last 10 years. As of 2015, the share of the agroindustrial complex in the structure of the total export volume of Ukraine increased up to $27 \%$, thus outperforming metallurgical production $(21,6 \%)$, which always was the leader in terms of foreign trade. In the same year, national agricultural sector ranked seventh in wheat production, fifth in corn production, and third in barley production worldwide. In addition, Ukraine belongs to the world leaders in sunflower oil production and exports. In accordance with the national model's focus on economic cooperation with the EU, Ukrainian agriculture becomes an industry, attractive for investments and capable of providing investors with significant socioeconomic benefits from production.

Paice and Grimwood (2012) and Hanrahan (2013) researched conceptual and practical challenges in the development of agri-food export, especially in the context of evergrowing world concerns regarding food safety point. Such Ukrainian scientists as Antoniuk (2014) and Bestuzheva (2009) studied commodity and geographical diversification of export flows. Borodyna (2006), Saikevych (2013), and Kvasha and Vlasov (2015) dealt with the beneficial potential of exports, with special emphasis on Ukraine's association with the European Union. Klymenko (2014) analyzed the risks of the European integration project as such. Despite the progress made under the DCFTA, real-life experience has proven there still is a range of problems accompanying Ukrainian agri-food products' adaptation to the requirements and standards of European market. In addition, a certain dissymmetry exists between the basic terms and conditions of the free trade area agreement and the levels of economic development in participating countries, which can create certain risks for national manufacturers and problems for potential investors. Therefore, the aim of this research is to determine the possibilities and best directions in future development of Ukraine's agricultural sector export potential, stemming from the research of the Ukraine-EU DCFTA operating conditions and through construction of a gravity model, taking into account the potential adverse effects from highly competitive markets.

\section{RESEARCH TECHNIQUES}

For the preliminary analysis of the conditions of operation of the free trade area between Ukraine and the EU and determination of limits for the gravity model, the following information resources were used: the EUROSTAT (2017), the World Tariff Profiles (2015), the World Bank and the UNCTADstat, Ministry of Agrarian Policy and Food of Ukraine (2015), the official web site of the European Commission (2016), official web site of the State Fiscal Service of Ukraine (2016), official web site of the State Statistics Committee of Ukraine. Based on the data obtained from these resources, this paper will present the general characteristics of the Free Trade Area Agreement, the trade economic activity in the agri-food industry between Ukraine and the EU and a respective gravity model for the parties of the Agreement.

In general, gravity models represent one way to determine and assess the key factors affecting the development of international trade. The basis is Newton's law of gravitation from which trade between two countries is balanced based on the size of their economies and the distance between these countries 
(Zakharova, 2014). The gravity model was first proposed by Tinbergen (1962) and Anderson (1979). Though the gravity model was extensively used in empirical studies from the 1960s, the theoretical justification of the model has only recently been explored.

The equation proposed by Tinbergen (1962) is as follows:

$$
F_{i g}=G \frac{m_{i}^{a} m_{i}^{\beta}}{d_{i j}^{\delta}} \varepsilon_{i j}
$$

where $F_{i g}$ is the commodity turnover between countries $i$ and $j$,

$M_{i}$ and $M_{j}$ represent the gross domestic products of countries $i$ and $j$,

$d_{i j}$ is the factor of selling costs related to export, including logistic costs,

$\varepsilon_{i j}$ represents all other factors having effect on export but not included into the equation,

$\alpha, \beta, \delta$ are the constants (model parameters).

At the current stage, there are various interpretations of this model depending on the purpose of modeling. Thus, in the logarithmic form the gravity equation is expressed by the following formula:

$$
\ln \left(F_{i j}\right)=\beta_{0}+\beta_{1} \ln \left(M_{i}\right)+\beta_{2} \ln \left(M_{j}\right)+\beta_{3} \ln \left(D_{i j}\right)+\varepsilon_{i j} .
$$

The model contains an assumption that $\beta_{1}$ and $\beta_{2}$ will be positive while $\beta_{3}$ will be negative. The gravity model also influences other variables which may be added to the principal equation depending on the purpose of modeling.

The modeling techniques described above allow, based on the multifactor model, applying a mathematical approach to functional dependencies between the factors. In international practice the nature of processes depends on several values $-\mathrm{x}_{1}, \mathrm{x}_{2} \ldots \mathrm{x}_{\mathrm{k}}$ (Kostenko, 2012). The gravity model, in turn, allows taking into account the influence of each of the values. The gravity model can also determine the level of influence caused by crisis developments in the economy of one country on the other country and on bilateral trade in general.

To assess the parameters of this model, statistical data of the EU and Ukraine for the period between 1996 and 2015 were used. The EU GDP and Ukraine GDP were chosen as $M_{i}$ and $M_{j}$, respectively. To measure the distance between countries in this model, different values were chosen depending on the objectives and factual basis of the research. These objectives can relate to geographical distance or cargo transportation costs. In this case, $D_{i j}$ value was represented by the world quarterly or year-end average oil prices since their fluctuations change transportation costs.

\section{ANALYSIS OF DCFTA OPERATING CONDITIONS}

The deep and comprehensive free trade area (DCFTA) between Ukraine, on the one hand, and the European Union, European Atomic Energy Community and their member countries, on the other hand, came into force on the 1st of January, 2016, resulting in signing of the Association Agreement in 2014 (European Commission 2014). Implementation of the free trade regime with the promising trade and economic partners provides Ukraine with the possibility to diversify the geography and range of national export in the long term and attract significant investments to the branch.

The European Commission, by its Regulation No. 374/2014 (European Union 2014), introduced unilaterally the autonomous tariff preferences for the products originating from Ukraine, since 2014. In particular, $82.2 \%$ of duty rates for Ukrainian agricultural products were abolished. For part of the products, 
Ukrainian exporters gained an additional preference on goods, for which the EU proposed to determine tariff quotas. However, it should be noted that the initial conditions for DCFTA between the EU and Ukraine were non-symmetrical. The EU has a great number of specific and combined import duty rates while in Ukraine, import duty rates are mainly ad valorem. Unlike Ukraine, the EU uses a complex structure of combined rates for duty and an entry price system. Besides, the Union applies export subsidies and special protective measures for agricultural products to which Ukraine has no right. However, it should be mentioned here that the agricultural sector plays a much more important role for Ukrainian economy as compared with the EU countries (Table 1).

Table 1

Comparative analysis of agricultural indices of Ukraine and EU, average for the period of 2013-2015

\begin{tabular}{|l|c|c|c|}
\hline \multicolumn{1}{|c|}{ Index } & Unit of measure & EU-28 & Ukraine \\
\hline Share of agricultural lands & \% of total area of lands & 43.97 & 71.25 \\
\hline Agriculture value added & \% of GDP & 1.58 & 11.79 \\
\hline Agriculture value added per employee & USD & 25323.61 & 5495.34 \\
\hline Agricultural employment & $\begin{array}{c}\text { \% of all working } \\
\text { population }\end{array}$ & 4.42 & 14.80 \\
\hline Rural population & \% of all population & 25,43 & 30,52 \\
\hline Share of agricultural products export in total export & $\%$ & 9.1 & 30.9 \\
\hline Share of agricultural products import in total import & $\%$ & 10.2 & 11.1 \\
\hline Production of agricultural products & billion Euro & 369,58 & 16.44 \\
\hline Consumption of agricultural products & billion Euro & 354.95 & 10.28 \\
\hline
\end{tabular}

Source: Calculated according to data of International Trade Centre (2016), Project of Kyiv National Trade and Economic University and EU (2016), Melnyk (2015)].

The EU is an important trade partner of Ukraine in all segments. A significant increase in bilateral trade and economic cooperation was observed in 2008, which was preconditioned by Ukraine's accession to the WTP (World Trade Organization 2008). In the geographical structure of agricultural and food product exports from Ukraine, a share of EU countries is $28.2 \%$ (for comparison: Asian countries - $46.6 \%$, CIS $10.2 \%$, Africa countries - 13.6\%, countries of North America and South America - 0.8\%, other countries $-0.6 \%$ ). In the geographical structure of agricultural and food products import a share of EU countries is 45.1\% (for comparison: Asia countries - 21.4\% ,CIS - 9.1\% Africa countries - 5.4\%, countries of North America and South America - 13\%, other countries - 6\%).

The volume of commodity trade with EU countries is 28.5 billion USD or $38.2 \%$ of the total trade volume of Ukraine. EU is an important trade partner of Ukraine in the agricultural products sector too (commodity groups 1-24 of the harmonized System (HS)). European perspectives increased national cereal, oil and fruit potential and created a basis for the development of the meat sector and later, the milk complex in Ukraine. Dynamics of foreign trade with EU convincingly proves the strengthening of economic relations between Ukraine and EU, and it brings attention to the consolidation of a position concerning domestic products in the European market as well as the attractiveness of trade with EU countries. In particular, export of agro-industrial products for the period of 2006-2015 increased 2.7 times and for imported products 1.3 times (Fig. 1). The increasing attractiveness of EU market has been proved by a positive trade balance in recent years. In 2015, the positive balance reached a record level in Ukrainian history of over 2.4 billion USD being $17.5 \%$ more compared with the previous year. 


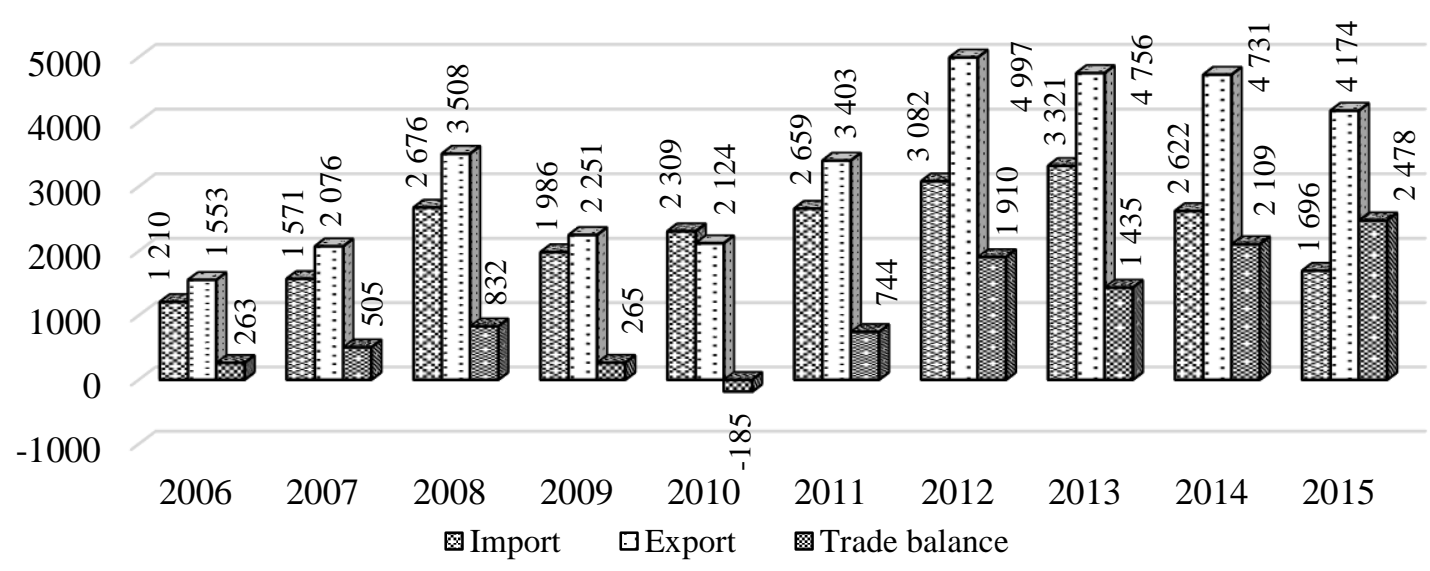

Figure 1. Dynamics of foreign trade in agro-industrial goods with EU countries in 2006-2015, million USD

Source: formed according to Demchak (2016), and Fryzorenko (2016), State Fiscal Service of the Ukraine (2016).

Participation of EU countries in trade and economic cooperation in the agricultural sphere is characterized by nonequivalence, i.e. from geographical point of view, import and export flows between EU and Ukraine have a significant level of concentration. In 2015, almost 70\% of export deliveries (Spain, Italy, Netherlands, Poland and France) and 63.2\% of import deliveries (German, Poland, France, Italy and Spain) fell on the largest five European partners. During 2006-2012 a share of EU in general Ukrainian import of all goods decreased from 37.1\% to 31.3\%, while during 2013-2015 this index increased up to $42.5 \%$. At the same time, EU countries provide a vast majority of food deliveries to Ukraine; thus, in 20062013 EU's share in Ukrainian import of agro-industrial products averaged between 38 and 39\%, but in 2014, it increased to $40.8 \%$, and in 2015 it reached a record $45.1 \%$.

These polar trends characterize Ukrainian exports to EU. A share of all exports to EU countries after the decrease in 2006-2009 tends to increase with priority rates in 2014-2015 after the signature of the Association Agreement with EU. At the same time, EU's share in Ukrainian export of agro-industrial products after the record levels of 2006-2008 (30-31\%) and the sharp decrease in 2009-2010 (20.8-23\%) since 2011 ranges from $26 \%$ to $28 \%$ (Fig. 2). Irrespective of the increase of trade between Ukraine and EU, according to EUROSTAT (2017), a share of trade in agricultural goods from Ukraine is still extremely small in the general foreign trade volume of EU countries. In 2015, Ukrainian share of agro food imports to EU countries was only $1 \%$.

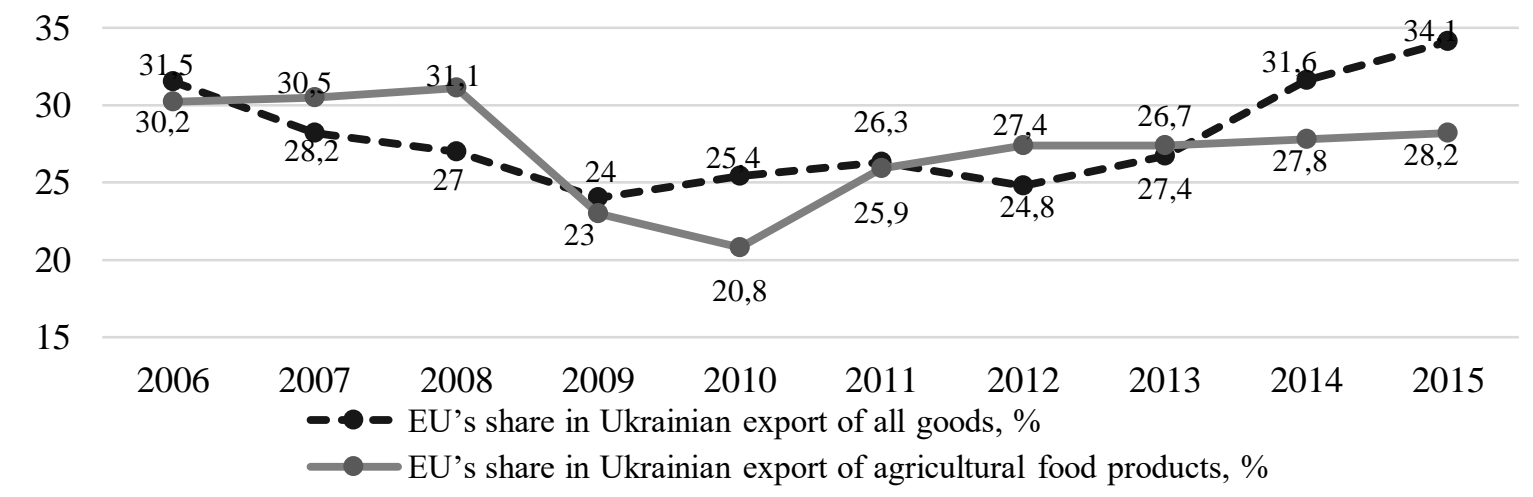

Figure 2. Dynamics of EU's share in Ukrainian export of goods, 2006-2015

Source: State Fiscal Service of Ukraine (2016). 
It should be mentioned that a significant portion of agricultural food exports from the EU includes goods with a high value added, especially in processed products. Agro-industrial imports from the EU is characterized by a diversified structure wherein a share of most products does not exceed $5 \%$ of the total import; however, a 5\% limit is exceeded only by corn (as seed material, feed components for animals (dogs and cats) and other food components). The total value of food product imports from EU countries in 2015 was 1169.8 billion USD, and food product exports to EU countries was 4174.2 billion USD.

Ukrainian exports of agricultural food products is characterized by a dependency on some main commodity items creating the danger of significant volume variations and values of export deliveries. In 2015, over half of the currency earnings from exports of the agro-industrial complex products was covered only by three groups of goods such as corn (30.5\%), sunflower oil (13.7\%) and oil meal and other waste products from manufacturing of sunflower oil (11.3\%).

The Ukraine export and import profit potential led to the DCFTA creation. This is evidenced by Ukraine's significant potential to increase its internal market, its steady and relatively high rate of economic development during recent years and EU's interest in deepening relations with foreign economic partners, which was characterized by expansion of access to resource sources. Meanwhile, European markets of agroindustrial products have become more open and transparent for domestic commodity producers since the creation of DCFTA. However, raw material orientation of the domestic export has had a negative effect on trade and economic activity. It should be noted that there is a potential medium — and long-term risk under the free trade conditions where some agricultural food products of Ukraine,(e.g., meat and milk products) are not competitive on EU markets.

One of the most important mechanisms of DCFTA implementation between Ukraine and the EU is application of tariff regulators specified in Part IV "Trade and Trade-Related Matters of the Agreement." For the moment, entry duty rates are approved by the Law of Ukraine "On the Customs Tariffs of Ukraine" (Verkhovna Rada of Ukraine 2014). Specific rates are 1\% of the total number of rates and determined for alcohol and tobacco products, the combined rates have not been determined up to date. The Customs Tariff of Ukraine includes 1357 differentiated preferential and full rates. Detailed information on the current rates of the cumulative Customs Tariff of Ukraine as of January 1, 2016 is shown in Table 2.

Table 2

Entry duty (preference rates) imposed on goods imported to the customs territory of Ukraine as of January 1, 2016

\begin{tabular}{|c|c|c|c|c|c|c|c|c|c|}
\hline \multicolumn{10}{|c|}{ Cumulative Customs Tariff of Ukraine } \\
\hline Duty rates, $\%$ & 0 & $0,1-5$ & $5,1-10$ & $10,1-15$ & $15,1-20$ & $20,1-25$ & $\begin{array}{c}\text { Over } \\
25\end{array}$ & $\begin{array}{l}\text { Specific } \\
\text { rates }\end{array}$ & Total \\
\hline $\begin{array}{l}\text { Number of commodity sub- } \\
\text { categories, item }\end{array}$ & 3961 & 2915 & 2406 & 765 & 296 & 5 & 10 & 105 & 10463 \\
\hline $\begin{array}{l}\text { Share of all commodity sub- } \\
\text { categories, } \%\end{array}$ & 37,86 & 27,9 & 23 & 7,3 & 2,8 & 0,05 & 0,1 & 1 & 100 \\
\hline $\begin{array}{l}\text { Average rate according to tariff } \\
\text { corridors, } \%\end{array}$ & - & 3,9 & 8,9 & 13,2 & 19,9 & 25 & 48 & - & - \\
\hline \multicolumn{10}{|c|}{ Maximum level of entry duty rate for preference ad valorem rates: $50 \%$. } \\
\hline \multicolumn{3}{|c|}{ For names of the groups 1-24: } & \multicolumn{7}{|c|}{$\begin{array}{c}50 \% \text { (of which for } 0,3 \% \text { of commodity sub-categories the entry } \\
\text { duties is determined over } 25 \% \text { ) }\end{array}$} \\
\hline \multicolumn{3}{|l|}{ For names of the groups 25-97: } & \multicolumn{7}{|c|}{$25 \%$ (only $0,1 \%$ of commodity sub-categories) } \\
\hline \multicolumn{3}{|l|}{ Average rate of Customs Tariff, $\%$} & \multicolumn{7}{|c|}{4,9} \\
\hline
\end{tabular}

Source: prepared based on Verkhovna Rada (Parliament) of Ukraine 2014, Storozhchuk (2016), World Tariff, (WTO, ITC, UNCTAD 2015). 
Ukraine opens, step by step, its market for the goods produced in the EU. Liberalization of the customs tariff of Ukraine will be continued under the Agreement, since arrangements on the creation of the free trade area will be fulfilled during the transition period covering a maximum of 10 years as determined by Article XXIV of GATTT of 1994 (WTO 1994). According to the arrangements reached, each party shall reduce or cancel the duty of goods as per the determined schedules, and the transition period for Ukraine will be up to 10 years. The change of the EU tariff schedule took place immediately upon the start date of the Agreement, January 1, 2016.

It should be noted that the EU market is noted for having a better tariff shelter. Agro-industrial goods have a current $5.3 \%$ average rate of entry duty. In Ukraine, the average rate of entry duty is $4.5 \%$. The agrofood HS 1-24 Group (agriculture) has a custom entry duty rate of $12.2 \%$, and a $9.2 \%$ rate for the Ukraine. At the same time, entry duty rates on the part of EU in specific tariff lines are 1.5-14 times higher than entry duty rates of Ukraine (WTO, ITC, UNCTAD, 2015).

The research and analysis of the text of the Free Trade Area Agreement shows a mutual agreement between the parties concerning the change of the procedure of tariff protection of the national agricultural food market in regard to the commodity group 1-24 HS Ukraine which had to reduce the existing average rate tariff shelter on agro food products from 6.8\%, upon the effective date of the Agreement by 1.3 of that level as of the $11^{\text {th }}$ year Agreement term. At the same time, the EU had to reduce its existing average rate of entry duty by $0.6 \%$ upon the same date. Thus, Ukraine agreed to reduce the level of tariff shelter of agricultural food products according to commodity items 1448, being 192 commodity levels higher than EU opens for Ukraine (Figure A1).

The highest level of tariff protection is peculiar to the milk and milk products market of EU, where the average tariff in 2014 was $42.1 \%$, while in Ukraine, it was only $10 \%$; sugar and confectionery was $25.2 \%$. but in Ukraine, the tariff was 19.4\%; EU average tariff in 2014 for beverages and tobacco products was $20.7 \%$, in Ukraine, it was $7.9 \%$; EU average tariff for meat and semi-finished meat products was $17.7 \%$, but in Ukraine it was $10.6 \%$; for grains, EU's tariff was $14.9 \%$, but Ukraine tariffs were $12.4 \%$; The EU tariffs for vegetables was $0.94 \%$, and in Ukraine, it was 9,8. The maximum animal products tariffs in EU exceed $138 \%$ due to application of tariff quotas for $4.8 \%$ of the tariff lines, which are a major portion of agricultural products. The tariff quotas cover for $11.3 \%$ of agricultural products' tariff lines. Ukraine applies a tariff quota only to sugar cane with an import tariff of $50 \%$ above the average scale (Table A1).

The Deep and Comprehensive Free Trade Area (DCFTA) agreement between Ukraine and EU (European Commission 2014, Shirmammadov, 2015) also provides abolishment of EU export subsidies, abolishment of export duties, regulation of the conditions of application of bilateral protective measures, harmonization of the technical regulation system, sanitary and phytosanitary protection.

Introduction of the tariff quota and respective reduction of entry duties in the EU were established to provide an increase in the export of Ukrainian agro-industrial products. According to economic estimates, annual increase of non-quota and quota Ukrainian export during the first year of the Agreement was expected to produce an increase in trade volumes of not less than $38.6 \%$ increase; however, during the following years the increase is predicted to be essentially less with an average of around $6.1-7.8 \%$. The increase in export of grain crops, meat and different food derivatives, such as tobacco products, were the most dependable part of the prediction. The economy or revenues of exporters because of freedom from payment of the tariff and abolishment of EU export duty under the quota is expected to reach EUR 180200 million. As for Ukrainian food market, the corresponding reduction by Ukraine of entry duties was predicted to lead to a $7 \%$ annual increase in imports due to the increase of the volumes of supply of beverages, meat and byproducts, milk products, and for a part of fruits and vegetables (Table A2). 
According to the Ministry of Agrarian Policy and Food, previous exporters of products to the EU had fully used up their quotas. From the moment their trade quotas were totaled, their competitive advantage increased slightly. It should be noted that the proposed quota volumes for these positions were relatively insignificant as shown in the 2015 data (reaching a benefit of only $35 \%$ as shown in Table A3.

Quotas for the following commodity groups are still not used up: lamb meat, sugar syrups, treated starch, mushrooms, products of treated milk, treated products of butter, malt and starch processing products, treated cereal products, treated products of milk cream, cigars and cigarettes.

\section{GRAVITY MODEL}

The gravity model was used to assess the effectiveness of the free trade area agreement and possible consequences of the deepening of integration cooperation. Among the econometric methods, gravity models are a main instrument used to model trade flows of countries. Therefore, based on the detailed analysis of the scope, capabilities and limitations of such models, gravity model instruments were used to assess the efficiency of trade cooperation between the Ukraine and EU. The basic data for building the gravity model for agricultural products is shown in Table A4.

The Tinbergen (1962) gravity model equation describing the dynamics of the foreign trade turnover of agro-industrial products between Ukraine and EU for the period of 1999-2015 is as follows:

$$
\ln \left(F_{i j}\right)=-18,761+1,338 \ln \left(M_{i}\right)+0,127 \ln \left(M_{j}\right)+0,787 \ln \left(D_{i j}\right)
$$

Basic results of the model are shown in Table 3. Model evaluation by the main criteria has shown that the model is statistically significant. The determination coefficient is close to 1 , so it approximates data very well.

Table 3

Tinbergen (1962) gravity model results

\begin{tabular}{|l|c|}
\hline \multicolumn{1}{|c|}{ Index } & Value \\
\hline$\beta 0$ & $-18,761$ \\
\hline$\beta 1$ & 1,338 \\
\hline$\beta 2$ & 0,127 \\
\hline$\beta 3$ & 0,787 \\
\hline$R 2$ & 0,9555 \\
\hline$R$ & 0,9775 \\
\hline F fact. & 114,53 \\
\hline F critic. $(0,05)$ & 3,01 \\
\hline
\end{tabular}

This model shows that:

- increasing EU GDP by USD 1.0 will increase two-way agro-industrial commodity turnover by USD 1.338

- increasing GDP of Ukraine by USD 1.0 will increase foreign trade turnover of agro-industrial products by USD 0.127 ;

- increasing oil price by USD 1 will increase two-way agro-industrial commodity turnover by USD 0.787 .

Figure 3 shows the foreign trade turnover of agro-industrial products of Ukraine and EU in 1996-2015. 


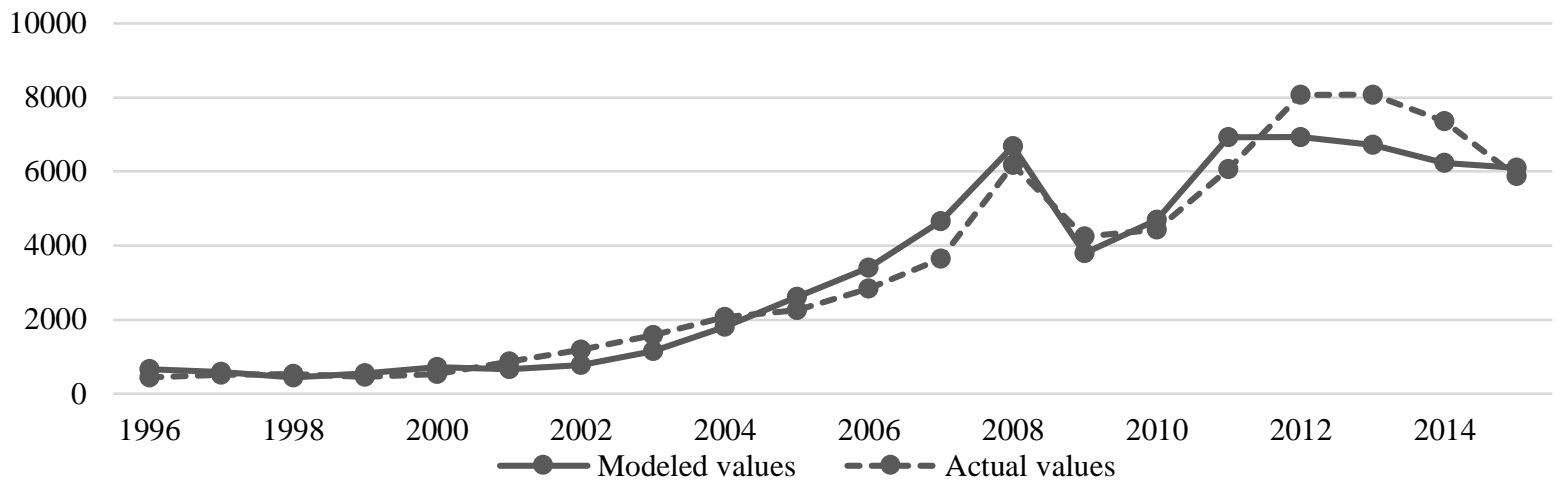

Figure 3. Actual and modeled values of foreign trade turnover of agro-industrial products of Ukraine and EU, million USD

Figure 4 shows the volume of bilateral trade in agro-industrial products between 2016 and 2020, which was forecast by means of the gravity model.

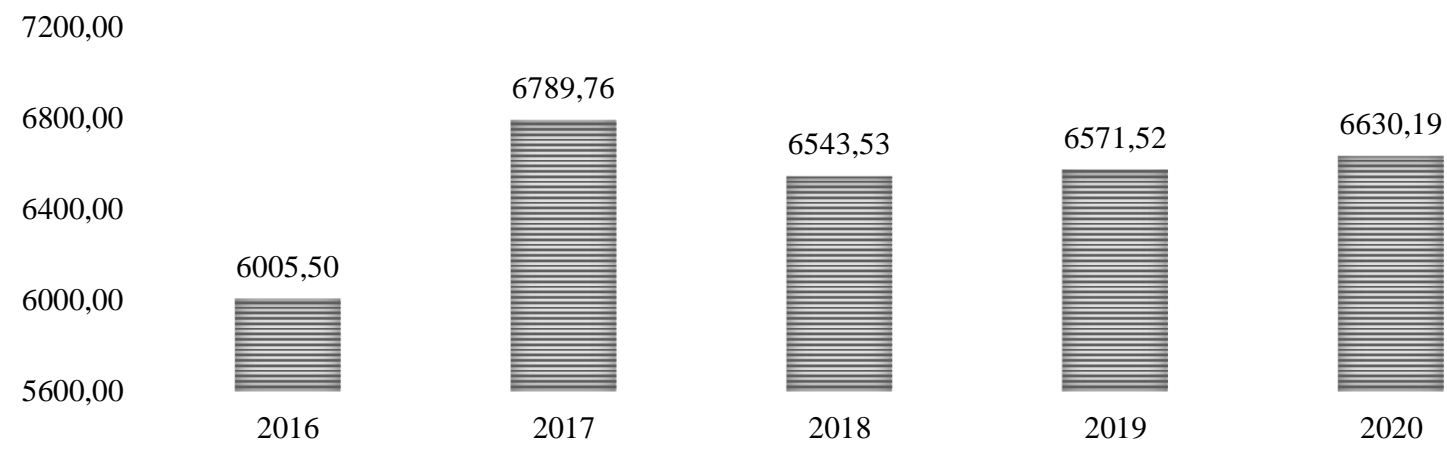

Figure 4. Forecasted turnover of agro-industrial products between the Ukraine and EU from 2016 to 2020, (in million USD)

Thus, calculation of the gravity model of foreign trade turnover of agro-industrial products between the Ukraine and EU clearly define a significant effect of the EU GDP economic growth. Ukrainian GDP growth rate has less effect, which can be explained by the differences in the size of EU and Ukraine economies. As for oil price, the effect is direct, i.e., increasing oil price promotes increasing commodity turnover between countries; however, gravity model findings provide an opposite effect. This phenomenon can be explained by the fact that countries are located at relatively short distances and transportation is not a main part of their expenses; thus, transportation is not critical to the state of commodity turnovers between countries.

\section{SOCIAL EFFECT}

Involvement of the national economy to the European labor division system by eliminating trade barriers and integrating Ukrainian economy into the European production networks creates preconditions for raising employment and labor productivity as a result of economic development of competitive industries, namely in the agricultural sector. However, we cannot ignore the threat of rising unemployment. Elimination of uncompetitive industries and increased labor productivity in many industries will increase 
the level of structural unemployment. This problem could severely weaken development of vocational training and retraining programs as well as programs designed to strengthen private entrepreneurship in the agricultural sector. In addition, deepened cooperation between the Ukraine and EU in the framework of the DCFTA comes amid worsening trade relations with Eastern partners, especially Russia. Although in theory any country can sign a DCFTA with other countries, creation by Ukraine of the DCFTA with the EU is seen in Russia as a threat to its economic interests, which consequently leads to increased trade barriers.

Table 4 shows social consequences of economic integration by several scenarios: 1) Continued cooperation on the autonomous EU trade preferences for Ukraine, which operated until 2016 and strengthened the effect of the free trade zone with Russia, 2) DCFTA; 3) DCFTA and unilateral cancellation of free trade with Russia.

Social consequences of regional integration of Ukraine, $\%$ of cumulative change

\begin{tabular}{|l|c|c|c|}
\hline & $\begin{array}{c}\text { Scenario 1: } \\
\text { Autonomous EU } \\
\text { trade preferences }\end{array}$ & $\begin{array}{c}\text { Scenario 2: } \\
\text { DCFTA }\end{array}$ & $\begin{array}{c}\text { Scenario 3: DCFTA } \\
\text { and cancellation of free } \\
\text { trade with Russia }\end{array}$ \\
\hline Welfare change & 1.10 & 12.3 & 6.30 \\
\hline Urban households & 0.70 & 9.51 & 4.32 \\
\hline Rural households & 0.98 & 9.41 & 4.68 \\
\hline Poor households & 0.60 & 8.86 & 3.97 \\
\hline Non-poor households & 0.79 & 10.20 & 4.76 \\
\hline Change of wages of unskilled workers & 1.90 & 10.50 & 5.40 \\
\hline Change of wages of skilled workers & 1.50 & 10.80 & 5.90 \\
\hline
\end{tabular}

Source: Institute for Economic Research and Policy Consulting, (2014).

Analysis of the impact of DCFTA on different social groups shows that the benefits will increase for all categories of households, but the growth rate will vary, which may increase the gap between different sectors. The first issue here is that of poverty. According to calculations, the creation of the EU-Ukrainian DCFTA will lead to an increase non-poor household benefits by $10.2 \%$ in the long term, while poor household welfare will grow only by $8.9 \%$.

Benefits growth of poor and non-poor households is closely correlated with other indicators, namely with change of benefits depending on the level of skills of the households members, which affects the poverty level. Creation of DCFTA means higher wage growth rates primarily for skilled personnel. This statement finds confirmation in the benefits growth rate of households distributed by skills: higher skills mean higher benefits growth rates. At the same time, due to the high growth rate of agriculture through DCFTA, very close benefits growth rates for households located in rural and urban areas are observed.

\section{CONCLUSIONS AND DISCUSSION OF THE RESULTS OBTAINED}

For the Ukrainian agricultural sector, European economic integration will lead to the modernization of domestic enterprises, attraction of foreign investments and advanced technologies, competitive recovery of Ukrainian products, new financial resources for economic development and improvement of its citizens' living standards. However, the DCFTA does not guarantee the beginning of this Ukrainian integration process. Ukraine's integration into EU will be lengthy because of problems and tasks that need to be completed before the Ukrainian agricultural sector can be fully developed. The raw material orientation of 
Ukrainian exports reveals a low-paying capacity of agricultural producers as well as technological underdevelopment agriculture.

The main advantage of DCFTA for agricultural trade consists in the partial elimination of asymmetry in the trade conditions between EU and Ukraine which increased after Ukraine joined the World Trade Organization (WTO). The asymmetry decreases due to the reduction an average rate of customs tariff for agricultural products from $23.8 \%$ to $0.3 \%$ and for food products from $23.2 \%$ to $0.7 \%$, and introduction of tariff quotas with a zero rate for Ukrainian exports to the EU, which promotes a $15 \%$ increase in the turnover of agricultural food products by 2017. Other DCFTA advantages are:

- abolishment of export subsidies for EU agricultural products exported to Ukraine,

- harmonization of standards with EU facilitating access of domestic products to the EU market,

- implementation of agricultural producer support mechanisms,

- strategy development and improvement of branch development planning at different hierarchical levels due to modernization of the state agrarian policy according to EU legislative requirements,

- integration of the agrarian policy and agrarian region development policy into general European policy,

- introducing new opportunities for the cooperation,

- sharing experience and technologies in the field of organic farming and bio-technologies,

- possibilities of compensation to Ukraine for increase in raw material prices due to the abolishment of export duties at the expense of application of an additional duty during the 15 years of this Agreement,

- the perspective modernization of state agrarian and trade policies according to EU legislative requirements,

- improvement of the business environment due to the simplification of regulatory rules, and

- deregulation in the branch and diversification of export flows of agricultural food products.

In addition, implementation of EU strategy concerning small- and medium-scale business development and business development in niche branches (for example, berry, mushroom farming) will serve as an impetus for Ukraine entrepreneurship along with the creation of preconditions for vertical integration, as indicated by clusters of development in production, processing, and distributing, as well as by servicing cooperatives. The DCFTA will be a springboard for growth in employment and local communities due to the development of rural territories.

Analysis of DCFTA impacts different social groups, which leads to several important conclusions: First, all categories of households will benefit from the creation of DCFTA, even if Russia imposes trade restrictions. Second, welfare growth rates will differ for different categories of households, which means increasing the social gap. This primarily affects poverty because increased welfare of non-poor households will be $10.2 \%$ in the long term, while welfare growth of poor households will be $8.9 \%$. At the same time, due to expected high growth of agriculture under the DCFTA very close welfare growth rates for households located in rural and urban areas will be observed.

The risks may include: improvement of competition and internal markets due to decreases in weighted average entry duty rates for agricultural products ranging from $4.2 \%$ to $0.9 \%$. For finished food products, these duty rates will fluctuate between $10.3 \%$ and $3.6 \%$ during the 10 years of the agreement. These fluctuations may require additional financing from the state budget and an increase in institutional capability of the respective state authorities. Raw material prices are expected to increase due to the abolishment of export duties (e.g., sunflower seeds needed to produce sunflower oil). 
Significant risks are connected with the high value of Ukrainian adjustment in the technical regulation field to accommodate EU legislation. The costs are related not so much with the legislative implementation of appropriate standards as with the implementation of new technologies in production, procurement of appropriate equipment, personnel training etc. The experience of post-socialist countries which have become EU members shows that these procedures were financed mainly at the expense of the EU, the World Bank and other international organizations. Thus, the World Bank provided USD 41 million for the project of modernization of beef houses in Hungary, USD 71 million for the component of sanitary and phyto-sanitary standards within the project of Poland's export increase (Ostashko 2013). The total costs of modernization of production of animal and vegetable products according to EU standards are estimated to be EUR 900 million during 10 years of implementing the DCFTA (Heits 2014). Under the conditions of a general economic recession and military and political conflict with Russia, it is extremely difficult for Ukraine to find free financial resources for the support and stimulation of corresponding transformations in exportoriented industries.

Besides, there is a risk of restricting Ukrainian products' access to European markets on the pretext of their non-conformance to European standards and certificates. The narrowing of the export segment is due to several factors: 1) the removal from the free trade regime of almost 400 commodity items (mostly agricultural products), 2) trade liberalization designed to be the most profitable for Ukraine, 3) implementation by EU of a tariff quota discriminatory system at a very low level (for most kind of products there quotas are below $6 \%$ of the volume of EU volume for these kinds of products (grain, meat etc.), 4) abolishment of export duty for sunflower oil, which could leave domestic refineries without raw materials, 5) maintenance in EU of the system of multibillion agrarian sector support grants making the export of Ukrainian products to EU and third countries non-competitive.

According to the results of a Ukrainian business survey carried out by the institute of Economic Research and political consultations in May of 2016, more than 30\% of the food industry enterprises managed to commence or increase their export to EU after the DCFTA went into effect; however, the main obstacles preventing the usage of all advantages of the free trade area were considered by producers to be the incapacity to quickly adjust their products to EU requirements (about 30\% of respondents). Other problems as shown by Figure 5, were the absence of partners and the lack of credits and investments. Therefore, the government has prioritized the task of achieving macroeconomic stability, which can benefit from a reduction in the National Bank of Ukraine's rate thereby improving business access to credits and promote an increase in investments.

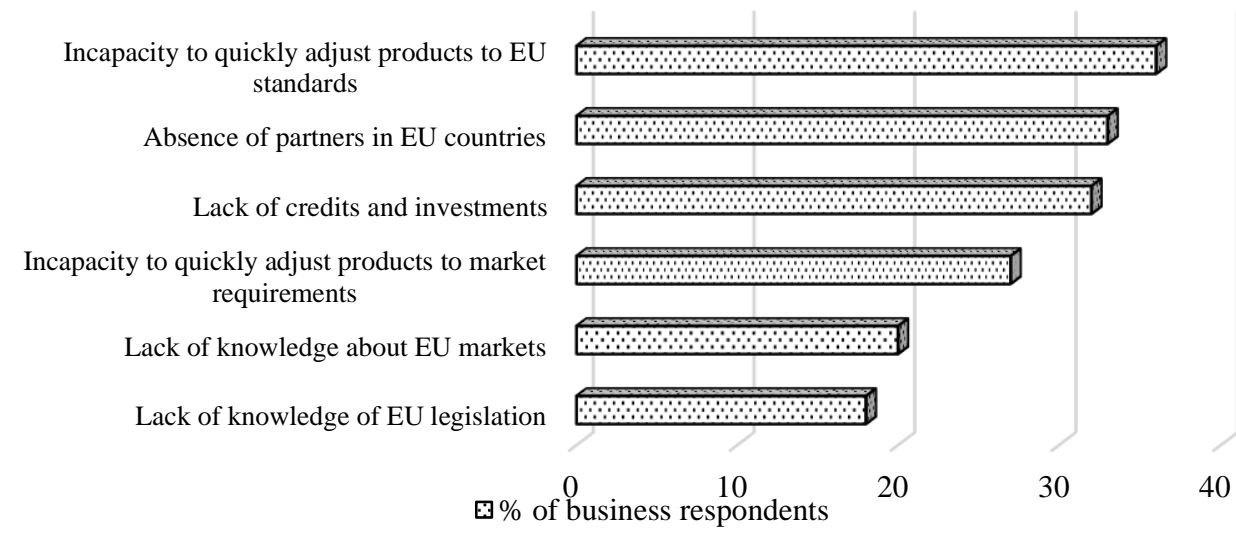

Figure 5. Obstacles preventing Ukrainian producers to enter European markets

Source: (Institute of Economic Research and Policy Consulting (2016) article entitled: Has Ukrainian

Business Benefited from the Creation of the DCFTA with EU? 
In addition, the successful implementation of the DCFTA Agreement between Ukraine and EU will be promoted by harmonization of market and state regulatory methods with simultaneous adjustment of national legislation to accommodate EU legislative requirements in the priority spheres. The objective is to accelerate the negotiation process concerning a new format of relations in economy, foreign trade, regional and social policy, industrial and cross-border development. Those implementing the DCFTA will also be monitoring environment protection and ecological safety, effective application of economic diplomacy methods to overcome barriers while exporting products to European markets in the long-term. In this case, the first steps to the creation of an effective mechanism to provide DCFTA adaptation information to business participants as well as legal and other state support to exporters. Success will allow Ukrainian businesses to prosper and attract foreign investment and commercialization of projects.

In order to minimize risks for the agrarian sector connected with the establishment of the EUUkrainian DCFTA, leaders must improve the principles of an Euro-integration policy to accelerate works on the program of agro-industrial complex adjustment to operation under the conditions of the common European market and a common agrarian policy. This policy must promote the formation, correction and implementation of the Ukrainian agrarian and trade policy, synchronizing national reforms with Eurointegration to improve investment in agriculture. Ukraine has already implemented DCFTA provisions concerning administration of commodity origin and tariff regulators, especially the implementation of the regulatory and legal framework. Software information systems have been provided. A place to issue certificates has been established, which is close to the potential exporters/producers. A mechanism to authorize (approve) exports for the determination of product origin has been introduced. This mechanism simplifies the application process with an instrument of Ukrainian origin than can offer confirmation for supplies delivered to EU.

In the context of globalization, all sectors of national economies become interdependent, mutually conditioned and complementary, and the place and role of the state in the world economy is determined by the number of exportable branches and the volume and value of environmentally sustainable standardized products. The formation and support of the strategic export generating sectors of economy able to create global products is a priority task of the state.

\section{REFERENCES}

Anderson, J. (1979). A theoretical foundation for the gravity equation. American Economic Review, 69, 106-116.

Antoniuk, O. P. (2014). Agri-food Export Analysis. Food Industry Economics, 3(23), 27-32.

Bestuzheva, S. V. (2015). Foreign Trade Development Directions in the Agriculture of Ukraine. Global and National Economic Problems, 4, 41-45.

Borodina, O. M. (2006). Agricultural Sector of Ukraine on the Way Towards European Integration: monograph. Uzhgorod: IBA: 109-119.

Demchak, I., Mytchenko, O., \& Maidaniuk, O. (2016). Foreign trade of Ukraine in agro-industrial products with EU countries. Kyiv: Research Institute "Ukragropromproduktyvnist".

European Commission. (2013). EU-Ukraine Deep and Comprehensive Free Trade Area, Reading Guide. Retrieved from https://trade.ec.europa.eu/doclib/docs/2013/april/tradoc_150981.pdf

European Commission. (2014). Deep and Comprehensive Free Trade Area (DCFTA) between Ukraine and EU, Association Agreement. Official Journal of the European Commission, 161 pages, Released May 29, 2014. Retrieved from http://trade.ec.europa.eu/doclib/docs/2016/november/tradoc 155103.pdf

European Commission. (2016). Addition to Annex I-A to the Association Agreement between Ukraine on the one part and European Union and its member countries on the other part. Accessed November 2016. Retrieved from http://www.kmu.gov.ua/docs/Agreement/Annex I-A to Agreement.pdf.

European Commission. (2016). Official website. December 2016. Retrieved from http://www.eur-lex.europa.eu. 
EUROSTAT. (2017). Database. Accessed January 2017. Retrieved from http://ec.europa.eu/eurostat

European Union. (2014). Regulation (EU) No 374/2014 of the European Parliament and of the Council of the European Union, EUR-Lex - 32014R0374 - EN. Official Journal of the European Union. Retrieved from http://eurlex.europa.eu/legal-content/EN/TXT/?uri=CELEX\%3A32014R0374

Fryzorenko, A. (2016). Foreign trade of Ukraine in goods and services in 2015: statistical book. Kyiv: State Statistics Service of Ukraine.

Heits, V. (2014). Assessment of influence of the Association / FTA Agreement between Ukraine and EU on economy of Ukraine. Kyiv: "Institute of Economics and Forecasting.

Institute of Economic Research and Policy Consulting. (2016). Has Ukrainian Business Benefited from the Creation of the DCFTA with EU? Retrieved August 2016 from http://www.ier.com.ua/ua/publications/articles?pid=5358

Institute for Economic Research and Policy Consulting and International renaissance foundation. (2014). The effects of creation of deep and comprehensive free trade area between Ukraine and the EU/Institute for Economic Research and Policy Consulting. Retrieved December 2016 from http://www.ier.com.ua/files/Projects/report_2014-11-28_edited.pdf.

Klymenko, I. (2014). Risks of European Integration Project: challenges and opportunities for Ukraine. PhilSci archive. Accessed August 2016. Retrieved from http://www.niss.gov.ua/articles/1003/.

Kostenko, N. (2012). Methodology of research and determination of geo-economic priorities by countries in the process of regional integration. Bulletin of International Nobel Economic Forum, 1(5), 157-166.

Kvasha, S. M., \& Vlasov, V. I. (2013). Exports and Imports of the Agri-Food in Ukraine: Status and Trends. Kyiv: NSC IAE.

Kvasha, S. (2014). Signing of the Association Agreement between Ukraine and European Union: challenges and perspectives. Retrieved July 2016 from http://www.fem.sumdu.edu.ua/.../presentation_2014_last.pdf.

Melnyk, T., \& Holovachova, O. (2015). Foreign Economic Regulatory Policy in Agro-Industrial Sphere: national and foreign experience. Economic Annals-XXI, 3-4(2), 12-16.

Ministry of Agrarian Policy and Food of Ukraine. (2016). Official website. Retrieved January 2016 from http://minagro.gov.ua.

Ministry for Foreign Affairs of Ukraine. (2016). The Association Agreement between Ukraine and EU. Retrieved January 2016 from http://www.kmu.gov.ua/kmu/docs/EA/00_Ukraine-

EU Association Agreement (body).pdf.

State Fiscal Service of Ukraine. (2016). Official website. Retrieved January 2016 from http://sfs.gov.ua/.

State Statistics Committee of Ukraine. (2016). Official website. Retrieved January 2016 from http://www.ukrstat.gov.ua/.

Ostashko, T. (2013). Agricultural markets under the influence of expected changes in trade regimes. Retrieved December 2016 fromhttp://nbuv.gov.ua/UJRN/econprog $2013 \quad 3 \quad 9$.

Kyiv National Trade and Economic University and EU. (2016). Project "The Deep and Comprehensive Free Trade Area with European Union: advantages and disadvantages for Ukrainian society", common project of Kyiv National Trade and Economic University and EU, (certificate No. 562453-EPP-1-2015-1-UA-EPPJMOMODULE, 13.06-17.06.2016).

Ryzhenkov, M., Halko, S., \& Movchan, V. (2013). Influence of the Deep and Comprehensive FTA between EU and Ukraine on Agricultural Trade. Consulting work. APD/PP/01/2013.

Saykevych, M. I. (2013). Export Potential of Agricultural Enterprises. Innovative Economy, 41, 104-110.

Shirmammadov, K. (2015). DCFTA (Deep and Comprehensive Free Trade Agreement) in EU and Ukraine Relations. J Pol Sci Pub Aff, 3, 170. doi:10.4172/2332-0761.1000170

Storozhchuk, V. (2016). Realization of Tariff Regulation under the Association Agreement between Ukraine and EU. Ternopil: Publication and Printing Center of Ternopil National Economic University "Economic Thought".

Tinbergen, J. (1962). Shaping the World Economy; Suggestions for an International Economic Policy. Books (Jan Tinbergen). Twentieth Century Fund, New York. Retrieved from http://hdl.handle.net/1765/16826.

International Trade Centre. (2016). Trade statistics for international business development. Retrieved December 2016 from http://www.trademap.org/Product SelCountry TS.aspx?nvpm=

UNCTADstat. (2016). Online information. Retrieved December 2016 from http://unctadstat.unctad.org/EN/. 
Verkhovna Rada of Ukraine. (2014). On the Customs Tariff of Ukraine: The Law of Ukraine. 2014. Gazette of the Verkhovna Rada of Ukraine, 20-21, 740 .

Win-TV Instrument. (2016). Inexhaustible. How Ukrainian Exporters Used European Quotas. Retrieved December 2016 from http://pobedit.com.ua/prom-news/1035.

World Bank. (2015). Online information. Retrieved December 2016 from http://data.worldbank.org/indicator.

World Trade Organization (WTO), International Trade Centre (ITC), United Nations Conference on Trade and Development (UNCTAD) (2015). World Tariff Profiles, an annual publication containing a comprehensive compilation of the tariffs imposed by each of the 161 WTO members pus a number of other countries and customs territories. Retrieved December 2016 from https://www.wto.org/english/res e/booksp e/tariff profiles15 e.pdf.

World Trade Organization. (2008). WTO Welcomes Ukraine as a New Member, online press release. Retrieved from https://www.wto.org/english/news e/pres08 e/pr511 e.htm.

WTO. (1994). General Agreement on Tariffs and Trade 1994. WTO analytical index: GATT 1994, Article XIVV: Territorial Application - Frontier Traffic - Customs Unions and Free-trade Areas. Retrieved from https://www.wto.org/english/res_e/booksp_e/analytic_index_e/gatt1994_09_e.htm

Zakharova, O. (2014). Peculiarities of application of gravity models in the analysis of international trade cooperation. Bulletin of Mariupol State University. Economics, 8, 145-151. 


\section{APPENDIX}

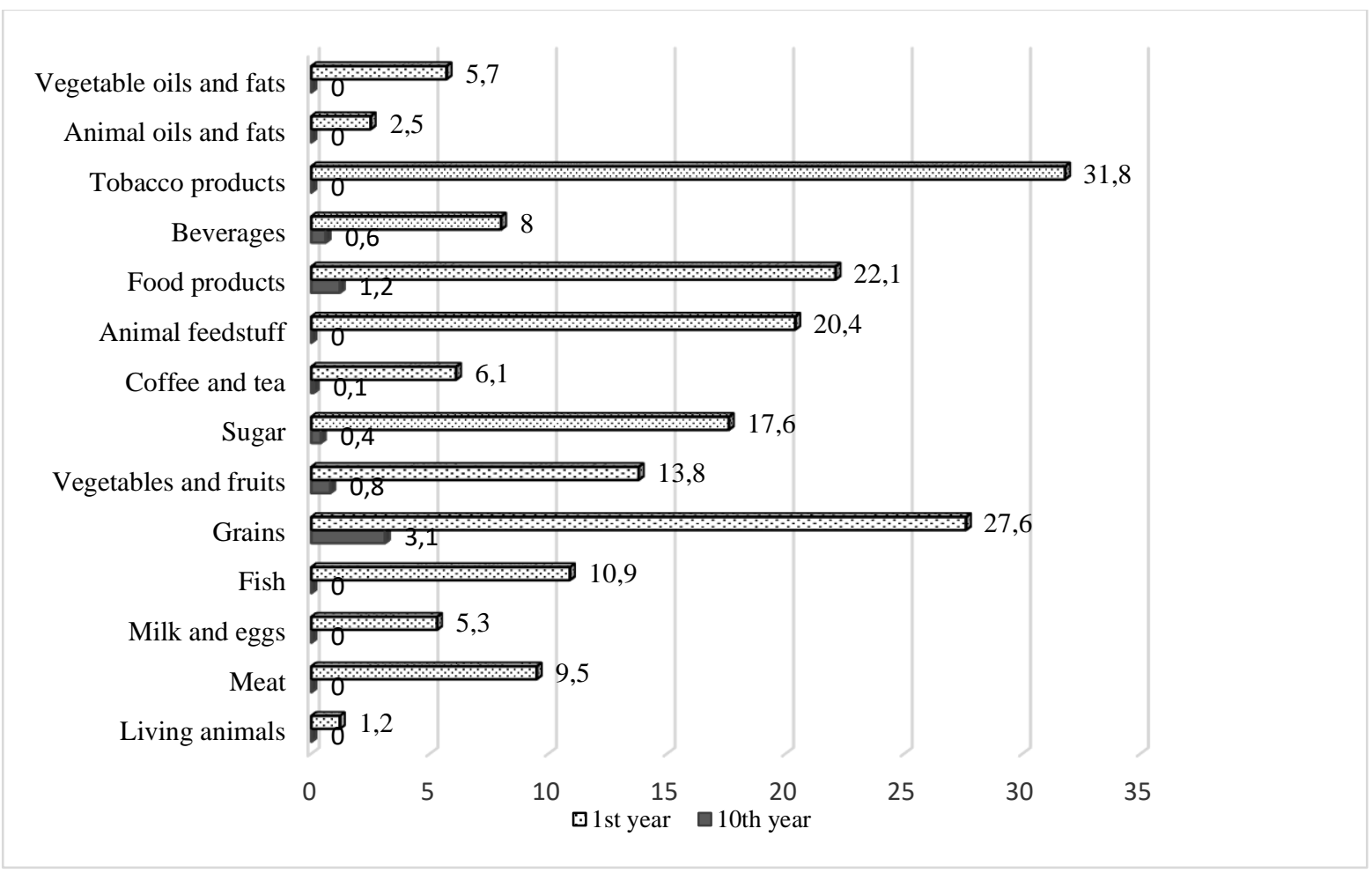

a) The initial level and the final level of tariff shelter of EU, \%

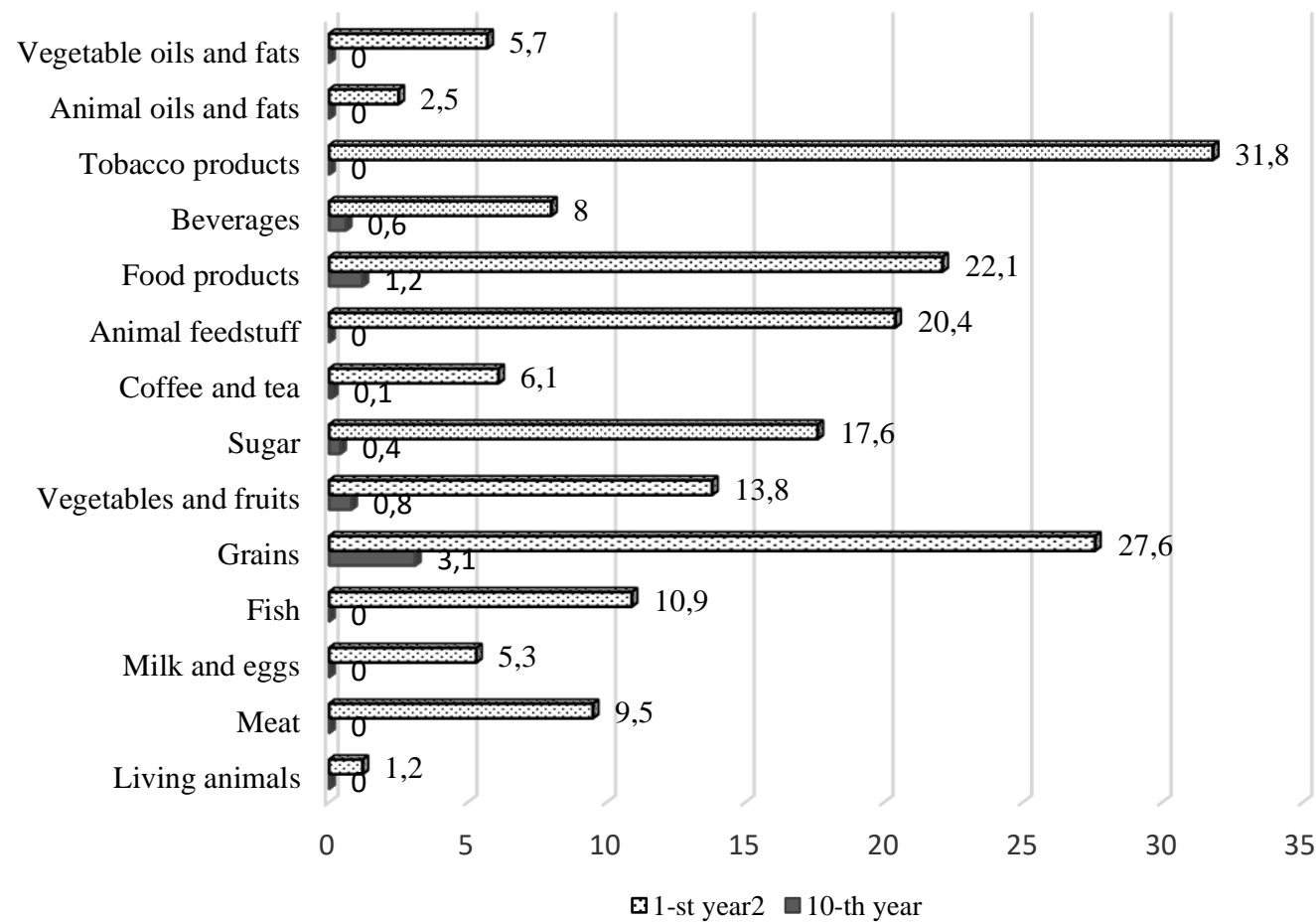

b) The initial and final level of Ukraine tariff shelter, $\%$

Figure A1. Changes in entry duties of EU and Ukraine based on individual agricultural products Source: (Ryzhenkov, 2013) 
Tariff quotas introduced by EU regarding imports from Ukraine

\begin{tabular}{|c|c|}
\hline Product & Stipulated quota \\
\hline Beef & $12000 \mathrm{t} /$ year \\
\hline Pork meat & $20000 \mathrm{t} /$ year $+20000 \mathrm{t} /$ year for some commodity groups \\
\hline Poultry meat and by-products & $\begin{array}{l}16000 \mathrm{t} / \text { year with gradual increase during } 5 \text { years up to } 20000 \mathrm{t} / \text { year } \\
+20000 \mathrm{t} / \text { year for some commodity groups }\end{array}$ \\
\hline $\begin{array}{l}\text { Milk, cream, condensed milk and } \\
\text { yoghurts }\end{array}$ & $\begin{array}{l}8000 \mathrm{t} / \text { year with gradual increase during } 5 \text { years } \\
\text { up to } 10000 \mathrm{t} / \text { year }\end{array}$ \\
\hline Lamb meat & $\begin{array}{l}1500 \mathrm{t} / \text { year with gradual increase during } 5 \text { years } \\
\text { up to } 2250 \mathrm{t} / \text { year }\end{array}$ \\
\hline Dairy butter and spreads & $\begin{array}{l}1500 \mathrm{t} / \text { year with gradual increase during } 5 \text { years up to } \\
3000 \mathrm{t} / \text { year }\end{array}$ \\
\hline Eggs and albumens & $\begin{array}{l}1500 \mathrm{t} / \text { year with gradual increase during } 5 \text { years up to } \\
3000 \mathrm{t} / \text { year }\end{array}$ \\
\hline Honey & $\begin{array}{l}5000 \mathrm{t} / \text { year with gradual increase during } 5 \text { years up to } \\
6000 \mathrm{t} / \text { year }\end{array}$ \\
\hline Sugar & $20070 \mathrm{t} /$ year \\
\hline Soft wheat, wheat flour and granules & $\begin{array}{l}950000 \mathrm{t} / \text { year with gradual increase during } 5 \text { years up to } \\
1000000 \mathrm{t} / \text { year }\end{array}$ \\
\hline Barley, barley flour and granules & $250000 \mathrm{t} /$ year with gradual increase during 5 years up to $350000 \mathrm{t} /$ year \\
\hline Corn, corn flour and granules & $400000 \mathrm{t} /$ year with gradual increase during 5 years up to $650000 \mathrm{t} /$ year \\
\hline Mill offal, wastes and remains & $\begin{array}{l}16000 \mathrm{t} / \text { year with gradual increase during } 5 \text { years up to } \\
21000 \mathrm{t} / \text { year }\end{array}$ \\
\hline Grape juice and apple juice & $\begin{array}{l}10000 \mathrm{t} / \text { year with gradual increase during } 5 \text { years up to } \\
20000 \mathrm{t} / \text { year }\end{array}$ \\
\hline Treated sugar products & $2000 \mathrm{t} /$ year with increase during 5 years up to $3000 \mathrm{t} /$ year \\
\hline Food stuff & $2000 \mathrm{t} /$ year \\
\hline Reference material & $\begin{array}{l}27000 \mathrm{t} / \text { year with gradual increase during } 5 \text { years up to } \\
100000 \mathrm{t} / \text { year }\end{array}$ \\
\hline Cigars and cigarettes & $2500 \mathrm{t} /$ year \\
\hline Mushrooms & $500 t /$ year $+500 t /$ year for some codes \\
\hline Treated tomatoes & $10000 \mathrm{t} /$ year \\
\hline
\end{tabular}

Source: prepared according to European Commission (2016). Addition to Annex I-A 
Tariff quotas introduced by Ukraine for import from EU

\begin{tabular}{|l|c|}
\hline \multicolumn{1}{|c|}{ Product } & Stipulated quota \\
\hline Pork meat & $10000 \mathrm{t} /$ year $+10000 \mathrm{t} /$ year for some commodity groups \\
\hline Poultry meat and by-products & $\begin{array}{r}8000 \mathrm{t} / \text { year with the possibility of increase during } 5 \text { years up to } 10000 \\
\mathrm{t} / \text { year }+10000 \mathrm{t} / \text { year for some commodity groups }\end{array}$ \\
\hline Sugar & $30000 \mathrm{t} /$ year with increase during 5 years up to $40000 \mathrm{t} /$ year \\
\hline
\end{tabular}

Source: prepared according to European Commission (2016). Addition to Annex I-A

Table A3

Calculation of value of Ukrainian quota goods export to countries of European Union

\begin{tabular}{|c|c|c|c|c|}
\hline \multirow[b]{2}{*}{ Name of good } & \multicolumn{2}{|l|}{$1^{\text {st }}$ year } & \multicolumn{2}{|l|}{$5^{\text {th }}$ year } \\
\hline & Quota, t & $\begin{array}{l}\text { Value, } \\
\text { million USD }\end{array}$ & Quota, t & $\begin{array}{l}\text { Value, } \\
\text { million USD. }\end{array}$ \\
\hline \multicolumn{5}{|l|}{ Animal products } \\
\hline Beef & 12000 & 130,3 & 12000 & 130,3 \\
\hline Pork meat & 40000 & 372,8 & 40000 & 372,8 \\
\hline Lamb meat & 1500 & 21,1 & 2250 & 31,6 \\
\hline Poultry meat & 36000 & 84,0 & 40000 & 93,3 \\
\hline Milk & 8000 & 30,0 & 10000 & 37,5 \\
\hline Cheese & 2000 & 23,1 & 2000 & 23,1 \\
\hline Honey & 5000 & 12,2 & 6000 & 14,6 \\
\hline Total animal products & & 704,2 & $\mathrm{x}$ & 762,2 \\
\hline \multicolumn{5}{|l|}{ Vegetable products } \\
\hline Wheat & 950000 & 257,1 & 1000000 & 270,6 \\
\hline Barley & 250000 & 66,7 & 350000 & 93,4 \\
\hline Corn & 400000 & 92,6 & 650000 & 150,4 \\
\hline Starch & 10000 & 30,3 & 10000 & 30,3 \\
\hline Total vegetable products & & 460,5 & & 559,4 \\
\hline \multicolumn{5}{|l|}{ Processed products } \\
\hline Sugar & 20000 & 10,5 & 20000 & 10,5 \\
\hline Grape juice & 10000 & 9,3 & 20000 & 18,6 \\
\hline Apple juice & 10000 & 18,4 & 20000 & 36,8 \\
\hline Protein concentrates & 2000 & 24,9 & 2000 & 24,9 \\
\hline Reference standard & 27000 & 25,6 & 100000 & 94,8 \\
\hline Cigars and Cigarettes & 2500 & 143,8 & 2500 & 143,8 \\
\hline Total processed products & & 260,2 & $\mathrm{x}$ & 362,9 \\
\hline Total agro-industrial products & & 1424,9 & $\mathrm{x}$ & 1684,5 \\
\hline Without pork and beef & & 921,8 & $\mathrm{x}$ & 1181,4 \\
\hline Without pork, beef and reference standard & & 896,2 & $\mathrm{x}$ & 1086,6 \\
\hline
\end{tabular}

Source: Ministry of Agrarian Policy ... (2016) 
Actual use by Ukraine of duty free quotas for agricultural products to EU countries, 2014-2015

\begin{tabular}{|c|c|c|c|c|c|}
\hline \multirow[b]{2}{*}{ Name } & \multirow{2}{*}{$\begin{array}{c}\text { Quota } \\
\text { volume, t }\end{array}$} & \multicolumn{2}{|c|}{2014} & \multicolumn{2}{|c|}{2015} \\
\hline & & Quota used, t & $\begin{array}{c}\text { Remaining } \\
\text { quota, } \mathrm{t}\end{array}$ & Quota used, t & $\begin{array}{c}\text { Remaining } \\
\text { quota, } t\end{array}$ \\
\hline Wheat & 950000 & 950000 & 0 & 950000 & 0 \\
\hline Corn & 400000 & 400000 & 0 & 400000 & 0 \\
\hline Barley & 250000 & 22721 & 227279 & 194200 & 55800 \\
\hline Sugar & 20070 & 522 & 19548 & 19851 & 219 \\
\hline Poultry meat & 36000 & 12360 & 23640 & 12000 & 24000 \\
\hline Mill offal, wastes and remains & 16000 & 1841 & 14159 & 3522 & 12478 \\
\hline Grape juice and apple juice & 10000 & 10000 & 0 & 10000 & 0 \\
\hline Treated tomatoes & 10000 & 10000 & 0 & 10000 & 0 \\
\hline Starch & 10000 & 725 & 9275 & 960.5 & 9039.5 \\
\hline Other sugar & 10000 & 350 & 9650 & & 10000 \\
\hline Malt and wheat gluten & 7000 & 1991 & 5009 & 5104 & 1896 \\
\hline Barley grain and flour & 6300 & 6300 & 0 & 6300 & 0 \\
\hline Treated sugar products & 1810 & 21 & 1789 & 319.8 & 1490.2 \\
\hline Honey & 5000 & 5000 & 0 & 5000 & 0 \\
\hline Oats & 4000 & 65 & 3935 & 4000 & 0 \\
\hline Garlic & 500 & 36 & 464 & 44 & 456 \\
\hline
\end{tabular}

Source: Ministry of Agrarian Policy... (2016), Win-TV Instrument (2016). 
Table A5

Main data of gravity model for agricultural products (commodity groups from 01 to 24 based on Ukrainian Classification of Goods of Foreign Economic Activity (Parts I-IV)

\begin{tabular}{|c|c|c|c|c|}
\hline Year & $\begin{array}{l}\text { Ukraine-EU foreign trade } \\
\text { operations, agro-industrial products, } \\
\text { million USD }\end{array}$ & $\begin{array}{l}\text { EU GDP, } \\
\text { million USD }\end{array}$ & $\begin{array}{l}\text { Ukrainian GDP, } \\
\text { million USD }\end{array}$ & $\begin{array}{l}\text { Oil price, } \\
\text { USD/barrel }\end{array}$ \\
\hline 1996 & 439,0 & 9748340 & 46146 & 20,5 \\
\hline 1997 & 516,5 & 9166693 & 51938 & 19 \\
\hline 1998 & 531,9 & 9482905 & 43374 & 12,7 \\
\hline 1999 & 453,8 & 9476802 & 32706 & 17,7 \\
\hline 2000 & 526,5 & 8807159 & 32375 & 28,3 \\
\hline 2001 & 859,1 & 8907736 & 39309 & 24,4 \\
\hline 2002 & 1190,1 & 9716129 & 43956 & 25 \\
\hline 2003 & 1571,9 & 11846291 & 52010 & 28,9 \\
\hline 2004 & 2067,3 & 13683147 & 67218 & 38,3 \\
\hline 2005 & 2255,2 & 14306697 & 89239 & 54,40 \\
\hline 2006 & 2844,2 & 15269348 & 111885 & 65,40 \\
\hline 2007 & 3647,1 & 17663569 & 148734 & 72,70 \\
\hline 2008 & 6183,7 & 19020507 & 188110 & 97,70 \\
\hline 2009 & 4236,5 & 17013493 & 121552 & 61,90 \\
\hline 2010 & 4433,4 & 16946307 & 141209 & 79,60 \\
\hline 2011 & 6061,9 & 18319753 & 169334 & 111,00 \\
\hline 2012 & 8073,7 & 17262975 & 182592 & 121,40 \\
\hline 2013 & 8077,4 & 17970797 & 188350 & 108,56 \\
\hline 2014 & 7352,8 & 18498059 & 135472 & 98,90 \\
\hline 2015 & 5870,0 & 25897283 & 123279,52 & 55,27 \\
\hline
\end{tabular}

Source: State Statistics Committee of Ukraine ... (2016), UNCTAD... (2016). 